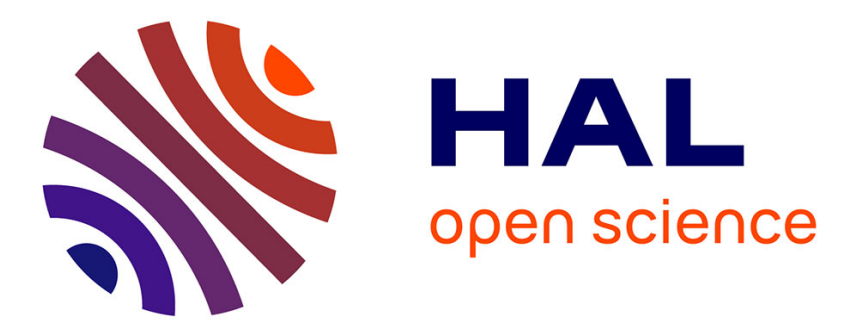

\title{
Modelling Greenland ice sheet inception and sustainability during the Late Pliocene
}

\author{
C. Contoux, C. Dumas, G. Ramstein, A. Jost, A.M. Dolan
}

\section{To cite this version:}

C. Contoux, C. Dumas, G. Ramstein, A. Jost, A.M. Dolan. Modelling Greenland ice sheet inception and sustainability during the Late Pliocene. Earth and Planetary Science Letters, 2015, 424, pp.295305. 10.1016/j.epsl.2015.05.018 . hal-01806173

\section{HAL Id: hal-01806173 \\ https://hal.science/hal-01806173}

Submitted on 11 Sep 2020

HAL is a multi-disciplinary open access archive for the deposit and dissemination of scientific research documents, whether they are published or not. The documents may come from teaching and research institutions in France or abroad, or from public or private research centers.
L'archive ouverte pluridisciplinaire HAL, est destinée au dépôt et à la diffusion de documents scientifiques de niveau recherche, publiés ou non, émanant des établissements d'enseignement et de recherche français ou étrangers, des laboratoires publics ou privés. 


\section{UNIVERSITY OF LEEDS}

This is a repository copy of Modelling Greenland Ice Sheet inception and sustainability during the Late Pliocene.

White Rose Research Online URL for this paper:

http://eprints.whiterose.ac.uk/85960/

Version: Accepted Version

\section{Article:}

Contoux, C, Dumas, C, Ramstein, G et al. (2 more authors) (2015) Modelling Greenland Ice Sheet inception and sustainability during the Late Pliocene. Earth and Planetary Science Letters, 424. 295 - 305. ISSN 0012-821X

https://doi.org/10.1016/j.epsl.2015.05.018

(C) 2015, Elsevier. Licensed under the Creative Commons Attribution-NonCommercial-NoDerivatives 4.0 International http://creativecommons.org/licenses/by-nc-nd/4.0/

\section{Reuse}

Unless indicated otherwise, fulltext items are protected by copyright with all rights reserved. The copyright exception in section 29 of the Copyright, Designs and Patents Act 1988 allows the making of a single copy solely for the purpose of non-commercial research or private study within the limits of fair dealing. The publisher or other rights-holder may allow further reproduction and re-use of this version - refer to the White Rose Research Online record for this item. Where records identify the publisher as the copyright holder, users can verify any specific terms of use on the publisher's website.

\section{Takedown}

If you consider content in White Rose Research Online to be in breach of UK law, please notify us by emailing eprints@whiterose.ac.uk including the URL of the record and the reason for the withdrawal request. 


\author{
Modelling Greenland Ice Sheet inception and \\ sustainability during the Late Pliocene

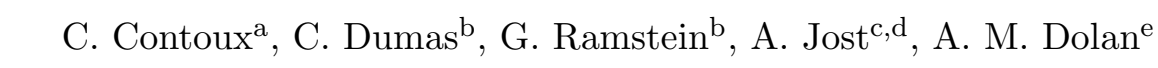 \\ ${ }^{a}$ Aix-Marseille Université, CNRS, IRD, CEREGE UM34, Aix-en-Provence, France. \\ E-mail: contoux@cerege.fr \\ ${ }^{b}$ Laboratoire des Sciences du Climat et de l'Environnement/IPSL, CEA/CNRS/UVSQ, \\ Gif-sur-Yvette Cedex, France. \\ ${ }^{c}$ Sorbonne Universités, UPMC Univ Paris 06, UMR 7619, Metis, F-75005, Paris, \\ France. \\ ${ }^{d}$ CNRS, UMR 7619, Metis, F-75005, Paris, France. \\ ${ }^{e}$ School of Earth and Environment, University of Leeds, Woodhouse Lane, Leeds, S29JT, \\ $U K$.
}

\begin{abstract}
Understanding the evolution and dynamics of ice sheet growth during past warm periods is a very important topic considering the potential total removal of the Greenland ice sheet in the future. In this regard, one key event is the full glaciation of Greenland that occurred at the end of the Pliocene warm period, but remains partially unexplained. Previous modelling studies succeeded in reproducing this full glaciation either by imposing an unrealistically low $\mathrm{CO}_{2}$ value or by imposing a partial ice sheet over the surface of Greenland. Although highlighting some fundamental mechanisms, none of these studies are fully satisfactory because they do not reflect realistic conditions occurring during the Late Pliocene. Through a series of simulations with the coupled climate model IPSL-CM5A used to force the ice sheet model GRISLI, we show that a drop in $\mathrm{CO}_{2}$ does not lead to an abrupt inception of the Grenland Ice Sheet (GrIS). High ablation rates in Central and North Greenland combined with low accumulation prevent such an abrupt inception. Ice sheet inception occurs when combining low summer
\end{abstract}


insolation and $\mathrm{CO}_{2}$ levels below modern values, the GrIS being restricted to the Southeast region where high topography favors this build-up. This ice sheet experiences only partial melting during summer insolation maxima combined with high $\mathrm{CO}_{2}$. Further growth of the ice sheet with recoupling experiments is important at $360 \mathrm{ppm}$ and $280 \mathrm{ppm}$ during insolation minima. Thus, the full glaciation at 2.6 Ma could be the result of a cumulative build-up of the GrIS over several orbital cycles, leading to progressively more intense glaciations during low summer insolation periods. Although this result could be a shortcoming of the modeling framework itself, the gradual glacial inception interpreted from the oxygen isotope record could support our scenario.

\section{Introduction}

1.1. The story of the Greenland Ice Sheet from the Miocene to the Pleistocene

The very beginning of ice cover on Greenland is thought to date back to

5 the late Miocene, with the build-up of an ice sheet on southern Greenland (e.g. Wolf and Thiede, 1991), which was made possible due to the mountain uplift in South and East Greenland (e.g. Japsen et al., 2006; Solgaard et al., 2013). This was followed by a gradual intensification of glaciation starting with the Late Pliocene, at around 3.6 Ma (Mudelsee and Raymo, 2005), peaking during Marine Isotope Stage (MIS) M2 around 3.3 Ma, and much lower ice volume during the mid-Piacenzian warm period (mPWP), between 3.3 to 3 Ma (see De Schepper et al., 2014, for a review), Central Greenland being most probably deglaciated after MIS M2 (Bierman et al., 2014). Ice rafted debris in the North Atlantic (ODP 907) depict an intensification of 
glacial intervals on Greenland starting at 3.3 and at 3.1-2.9 Ma (Jansen et al., 2000; Kleiven et al., 2002). The first IRD peak at 3.3 Ma is well correlated to the peak increase in $\delta^{18} \mathrm{O}$ of benthic foraminifera at MIS M2 (Lisiecki and Raymo, 2005; Mudelsee and Raymo, 2005). The MIS M2 event is accompanied by mean sea level estimates lower than today (De Schepper et al., 2014, and references therein), and is sometimes called a 'failed glaciation' which could be due to a southward shift of the North Atlantic Current driven by reduction of Pacific to Atlantic water flow through the Central American Seaway (De Schepper et al., 2009, 2013). After the MIS M2, during the mPWP, global ice volume is much reduced as shown by sea level estimates around +10 to $+40 \mathrm{~m}$ (Raymo et al., 2011), with a most probable mean value of $25 \pm 5 \mathrm{~m}$ (Dwyer et Chandler, 2009; Miller et al., 2012; Rovere et al., 2014). The GrIS inception was thus not a short term, single event, but rather followed a gradual long term trend from 3.6 to 2.4 Ma (Mudelsee and Raymo, 2005), and with an anomalous event, the MIS M2 glaciation. Large scale Northern Hemisphere glaciation then takes place around 2.7-2.5 Ma (Lisiecki and Raymo, 2005), or potentially later around 2.15 Ma (Rohling et al., 2014). This event determines the transition from the globally warm Neogene to the Quaternary climate oscillations of the glacial/interglacial cycles.

\subsection{Assessing the GrIS during the Late Pliocene}

Assessing the extent, volume and location of the GrIS during the Late Pliocene is important for two reasons. First, because of the multi stability of ice sheets (e.g. Solgaard and Langen, 2012), the initial state of the cryosphere on Greenland will modify the conditions necessary to form a 40 large Greenland glaciation around 2.6 Ma. In other words, if Greenland was 
completely deglaciated during the Late Pliocene, the $\mathrm{CO}_{2}$ level necessary to fully glaciate at 2.6 Ma would be lower than if Greenland was partially glaciated. Second, a more accurate extent of the GrIS is needed to be used as a boundary condition in climate modelling studies of the Late Pliocene, in particular for the second phase of the Pliocene Model Intercomparison Project (PlioMIP 2), which will focus on a narrower time slice (Haywood et al., 2013b).

Most previous studies investigating Plio-Pleistocene Greenland glaciation or sensitivity of the Pliocene GrIS assumed that Greenland was already partially glaciated. They used the PRISM2 (e.g. Lunt et al., 2008; Hill et al., 2010; Dolan et al., 2011) or PRISM3 boundary condition (Yan et al., 2014), for which GrIS volume is fixed to almost $50 \%$ of its present-day volume and covers about a third of Greenland, including its centre. Notably, using the PRISM2 boundary conditions, Lunt et al. (2008) demonstrated that a $\mathrm{CO}_{2}$ decline to $280 \mathrm{ppm}$ was causing Greenland to fully glaciate. The same experimental design was used by Dolan et al. (2011) to study GrIS extent changes related to insolation variations during the mid-Piacenzian warm period with the BASISM ice sheet model. Dolan et al. (2011) find that during periods of high summer insolation, GrIS vanishes, while its volume is around $35 \%$ of the present day one during periods of low summer insolation at $65^{\circ} \mathrm{N}$. The PRISM2 ice sheet is used as boundary condition in the coupled climate model HadCM3 in Lunt et al. (2008) and Dolan et al. (2011), and should help further GrIS inception during low summer insolation periods. On the contrary, Dolan et al. (2011) simulated ice sheet is smaller than the PRISM2 and PRISM3 ice sheets, revealing that neither PRISM2 or PRISM3 ice sheets could survive in the Pliocene climate. The same applies to Lunt et al. (2008), where the simulated ice sheet in Pliocene 
control conditions is much smaller than the imposed PRISM2 GrIS boundary condition. The PRISM2 reconstruction was based initially on sea level estimates and estimated contribution of Antarctic ice sheet to the sea level rise (Dowsett et al., 1999), providing a pioneering estimate of Greenland ice volume during the Late Pliocene. It was later refined for PRISM3, by modelling the GrIS with the BASISM ice sheet model in equilibrium with Pliocene climate simulated by the atmospheric model HadAM3, which was 75 itself forced with the PRISM2 SSTs, topography and GrIS reconstruction (Hill, 2009). These reconstructions assume the presence of an ice sheet over Central Greenland during the mid-Piacenzian warm period, which is highly uncertain in the light of recent results (Bierman et al., 2014; Koenig et al., 2015). In particular, Koenig et al. (2015) demonstrate using the PlioMIP climate ensemble that ice presence during the warm Pliocene must have been restricted to high topography regions in East and South Greenland.

Thanks to a large climate modelling effort followed by data-model comparisons, the Pliocene Model Intercomparison Project (PlioMIP) showed that the mid-Piacenzian time period was globally warmer than today, with important warming in the high latitudes, and more than $+10^{\circ} \mathrm{C}$ of warming on the deglaciated parts of Greenland (Haywood et al., 2013a; Dowsett et al., 2013). The vegetation reconstructions compiled by Salzmann et al. (2008, 2013) describe evergreen taiga on the Northeastern tip of Greenland, and alternating evergreen taiga/cool conifer forest off the southern tip of Greenland, attesting of a much warmer than present climate in these areas. In addition, a recent study of lacustrine sediments of the Lake El'gygytgyn situated in north-east Russia provides temperature estimates around 7 to $8^{\circ} \mathrm{C}$ warmer than today between 3.6 and $3.4 \mathrm{Ma}$, and around 3 to $6^{\circ} \mathrm{C}$ warmer between 3.26 and 2.2 Ma (Brigham-Grette et al., 2013). Although PRISM2 and 
PRISM3 reconstructions assumed that a subsequent ice sheet was already covering Greenland during the Pliocene, such elevated temperatures in the high latitudes seem unfavourable for the build-up of a sustainable ice sheet over Greenland. This view is supported by a transient modelling study by Berger et al. (1999) combining insolation variations and a linear decrease of $\mathrm{pCO}_{2}$ during the Plio-Pleistocene. Their study shows that between 3 to $2 \mathrm{Ma}$, Northern Hemisphere ice sheets cannot develop during small eccentricity periods, during which insolation is never low enough to allow for ice to grow. They show that during the Pliocene, ice sheets can create only during high eccentricity insolation minima and should melt during the following high eccentricity insolation maxima. More recently, Koenig et al. (2011) showed that the growth of a GrIS during the Late Pliocene was depending on orbital configuration and $\mathrm{CO}_{2}$ level, full glacial conditions being obtained with $200 \mathrm{ppm}$ of $\mathrm{CO}_{2}$ combined with low summer insolation. $\mathrm{pCO}_{2}$ reconstructions for the Pliocene vary greatly among studies, from low values around 280 ppm (Bartoli et al., 2011; Badger et al., 2013) up to high values around 410 ppm (Bartoli et al., 2011; Seki et al., 2010), while glacialinterglacial cycles during the Pliocene might be accompanied by 50 to 100 ppm amplitude $\mathrm{pCO}_{2}$ variations (Bartoli et al., 2011; Badger et al., 2013).

These studies demonstrate the need to further investigate which conditions are able to initiate the GrIS inception during the Late Pliocene, as well as its sustainability through the climate variability of this period, in order to understand which conditions can finally lead to the full glaciation of Greenland at the Plio-Pleistocene boundary. To answer these questions, we chose to test the impact on GrIS inception of imposing three different $\mathrm{CO}_{2}$ levels in the range of reconstructions (405, 360 and $280 \mathrm{ppm}$ ), combined with preindustrial, favourable or unfavourable orbit in our climate model starting 
first from deglaciated conditions. Second, we test the sustainability of the ice sheet in warmer conditions. Finally, we test the possibility of further growth of the ice sheet using cold conditions. These experiments allow us 125 to characterize the conditions leading to a full glaciation over Greenland.

\section{Method}

We use a set of Pliocene climates simulated with a fully coupled atmosphere ocean general circulation model, IPSL-CM5A (Marti et al., 2010; Dufresne et al., 2013), to force the ice sheet model GRISLI (Ritz et al., 2001). $\mathrm{CO}_{2}$ levels, insolation and ice sheet boundary conditions are modified in the various Pliocene climate simulations and all simulations (climate and ice sheets) are steady state. By doing this, we investigate which atmospheric $\mathrm{CO}_{2}$ levels and insolation forcings are compatible with the perennial build-up of the GrIS during the Pliocene. We divide our experiments into 3 different groups. Group 1 experiments (initiation) investigate the build-up of the GrIS, i.e. the climate model is forced with a completely deglaciated Greenland, corrected for isostatic rebound. Group 2 experiments (melting) are aimed to investigate the sustainability of the GrIS in warmer conditions. For group 2, the climate model is forced with the biggest ice sheet simulated in group 1, and higher $\mathrm{CO}_{2}$ and insolation to simulate a warmer climate. Finally, we carry out two continued growth experiments (group 3). Starting from previously simulated ice sheets, we aim to investigate the possibility to further grow the ice sheet in the same climate. For these continued growth experiments, we adopt the same procedure as for group 2, except that we

keep the same insolation and $\mathrm{CO}_{2}$ level as the ones used to previously create the ice sheet, in group 1 . These last experiments are a sensitivity test for 
our method which does not account for the ice-albedo feedback since the ice sheet model is not coupled to the climate model.

\subsection{The coupled climate model IPSL-CM5A}

150

We use the state of the art coupled atmosphere ocean general circulation model, IPSL-CM5A (Marti et al., 2010; Dufresne et al., 2013). The atmospheric module LMDZ5A has a resolution of $2.75^{\circ} \times 1.875^{\circ}$ and 39 vertical layers. Subgrid scale orographic drag is parametrised according to Lott (1999). Albedo of land ice is fixed to 0.77. In our study vegetation is not interactive and is fixed to the PRISM3 reconstruction (see2.3). The ocean model NEMO2.3 (Madec, 2008) uses a tripolar grid with horizontal curvilinear mesh (Madec and Imbard, 1996; Murray, 1996). Mean grid spacing is about $2^{\circ}$. Latitudinal resolution is refined to $0.5^{\circ}$ near the equator and $1^{\circ}$ in the Mediterranean Sea. There are 31 vertical levels in the ocean, with 10 levels in the top $100 \mathrm{~m}$. A total variance dissipation scheme is used for advection of temperature and salinity (Lévy et al., 2001; Cravatte et al., 2007). A conservation scheme of both energy and enstrophy is used in the momentum equation (Arakawa and Lamb, 1981; Le Sommer et al., 2009). The sea ice model is LIM2 and has two layers for snow and one layer for ice (Fichefet and Morales-Maqueda, 1997, 1999). Surface albedo of sea-ice is parametrised as a function of surface temperature and of snow and ice thicknesses. IPSL-CM5A and its previous versions have been extensively used and compared to data for the simulation of past climates (e.g. Kageyama et al., 2013; Woillez et al., 2014), including for the Late Pliocene climate 170 (Contoux et al., 2013; Leduc et al., 2013) and as part of the Pliocene Model Intercomparison Project (Contoux et al., 2012). 


\subsection{The ice sheet model GRISLI}

GRISLI is a 3-D thermo-mechanical ice sheet model which includes both grounded ice (Ritz et al., 1997) and ice shelves (Rommelaere and Ritz, 1996),

175 with a resolution of $40 \times 40 \mathrm{~km}$. The GRISLI ice sheet model has first been developed and validated for Antarctica (Ritz et al., 2001). It has later been used with different climate models to study paleostages of the Northern Hemisphere ice sheets, notably for the last glacial cycle (Peyaud et al., 2007; Bonelli et al., 2009; Charbit et al., 2013; Beghin et al., 2014, 2015).

180 A complete description of the model can be found in Ritz et al. (2001) and Peyaud et al. (2007). Grounded ice deformation calculation is based on the shallow ice approximation. Ice flow also depends on basal velocity, whether it is the ice sliding over the substrate or the deformation of the substrate. Individual ice streams are not explicitly resolved since their width do not exceed a few kilometers. Instead, ice flow through ice shelves is calculated using the shallow-shelf approximation (MacAyeal, 1989) using criteria based upon effective pressure and hydraulic load (Peyaud et al., 2007). Ice viscosity, basal sliding and basal melt depend on temperature. GRISLI accounts for isostatic response using the ELRA method (elastic lithoshere-relaxed asthenosphere). The isostatic adjustment of bedrock in response to ice load is governed by the flow of the asthenosphere, with a characteristic time constant of 3000 years, and by the rigidity of the lithosphere (Ritz et al., 2001). The ELRA method was compared to a fully self-gravitating solution by Le Meur and Huybrechts (1996). They show that among the simple methods of dealing with isostasy, ELRA is the most realistic (Ritz et al., 2001). The surface mass balance is the sum of accumulation and ablation calculated through the positive degree day (PDD) formula of Fausto et al. (2009), which has been shown to be more favourable to glaciation than 
other formulations (Reeh, 1991; Tarasov and Peltier, 2002) by Charbit et 200 al. (2013). The PDD formulation uses an altitude dependent formulation of the standard deviation of temperature distribution. The GRISLI model is forced with monthly 2-meter temperatures and total precipitation outputs from the climate model. Climate model outputs are regridded to the GRISLI grid with a bilinear interpolation. There is no parametrisation of sub-grid scale in GRISLI. Precipitation decreases exponentially in function of ice sheet altitude variation, following $P=P_{\text {init }} * \exp (0.05 * d h * l r)$, with $P_{\text {init }}$ the precipitation interpolated from the climate model, $d h$ being the altitude difference and $l r$ being the lapse rate of $6^{\circ} \mathrm{C} / \mathrm{km}$. Accumulation is then computed monthly on the GRISLI grid, depending on temperature. Under $2^{\circ} \mathrm{C}$, precipitation is solid (snow), liquid otherwise.

\subsection{Boundary conditions and experimental design}

\subsubsection{For the climate model IPSL-CM5A}

For the preindustrial control experiment, boundary conditions in the climate model are set according to CMIP5/PMIP3 guidelines. Greenhouse gases and orbital parameters are set to preindustrial values, $\mathrm{CO}_{2}$ content is $280 \mathrm{ppm}, \mathrm{CH}_{4}$ content is $760 \mathrm{ppb}$, and $\mathrm{N}_{2} \mathrm{O}$ content is $270 \mathrm{ppb}$. For all the Pliocene experiments, topography, vegetation and Antarctic ice sheet boundary conditions are set following the guidelines of the Pliocene Model Intercomparison Project (Haywood et al., 2010, 2011), except over Greenland. The Pliocene PRISM3 topography used is very similar to the present day one, except over Antarctica because the ice sheet is reduced. The Pliocene PRISM3 vegetation used is representative of a warmer than present climate, with reduced deserts and a northern shift of boreal forests biomes at the cost of tundra biomes. Detailed description of these boundary con- 
Table 1: Boundary conditions for the climate simulations. The first column indicates the name of the experiment. The second column indicates the boundary condition imposed on Greenland in the climate model. The initial ice sheet condition on Greenland in GRISLI is always consistent with (i.e. the same as) the ice sheet boundary condition in IPSL-CM5A. The name of the experiment can be deconstructed as follows : the first part, piControl or Plio indicates the time period simulated. The second part indicates the Greenland boundary condition ('noice' for deglaciated condition (group 1), 'ice' for group 2 and group 3 simulations). The third part indicates the insolation boundary condition: 'min' for minimum insolation, 'max' for maximum insolation, 'PI' when the imposed insolation corresponds to the preindustrial orbit. The fourth part indicates the $\mathrm{CO}_{2}$ level used as a boundary condition: 405, 360 or 280 ppm.

\begin{tabular}{lccc}
\hline Name of expt & Greenland & Insolation & $\mathrm{CO}_{2}(\mathrm{ppm})$ \\
\hline piControl & Modern & PI & 280 \\
\hline \multicolumn{4}{c}{ Group 1 experiments (growth) } \\
\hline Plio_noice_PI_405 & ice free & PI & 405 \\
Plio_noice_PI_360 & ice free & PI & 360 \\
Plio_noice_min_405 & ice free & min. & 405 \\
Plio_noice_min_360 & ice free & min. & 360 \\
Plio_noice_min_280 & ice free & min. & 280 \\
\hline & Group 2 experiments (melt) & & 360 \\
\hline Plio_ice_PI_360 & Plio_noice_min_280 simulated ice sheet & PI & 405 \\
Plio_ice_PI_405 & Plio_noice_min_280 simulated ice sheet & PI & 405 \\
Plio_ice_max_405 & Plio_noice_min_280 simulated ice sheet & max. & \\
\hline & Group 3 experiments (continued growth) & & 360 \\
\hline Plio_ice_min_360 & Plio_noice_min_360 simulated ice sheet & min. & 280 \\
Plio_ice_min_280 & Plio_noice_min_280 simulated ice sheet & min. & \\
\hline
\end{tabular}


Table 2: Orbital parameters used for the different insolation configurations (preindustrial, minimum and maximum). They were calculated using the Laskar et al. (2004) solution taking the summer solstice insolation at $65^{\circ} \mathrm{N}$.

\begin{tabular}{ccccc}
\hline Insolation & Eccentricity & Obliquity & Precession angle & Date \\
\hline PI (preindustrial) & 0.016715 & 23.441 & 102.04 & 1950 \\
\hline Maximum & 0.052115 & 23.641 & 271.41 & $3.039 \mathrm{Ma}$ \\
\hline Minimum & 0.05452 & 23.08 & 90.74 & $3.050 \mathrm{Ma}$ \\
\hline
\end{tabular}

ditions is available in Contoux et al. (2012), except for Greenland, which is entirely deglaciated and isostatically rebounded in the group 1 experiments (Fig. 1), in order to study the onset of glaciation (similar to PLISMIP phase 2, Dolan et al., 2012). Where GrIS is removed compared to the PRISM3 reconstruction, we replaced the ice by evergreen taiga, in agreement with the vegetation reconstruction of Salzmann et al. (2008), which shows evergreen taiga vegetation compiled from pollen data at three locations on Greenland. SSTs and sea-ice were initialised to Pliocene values, i.e. averaged from the last 50 years of a 1000 years Pliocene coupled model simulation used in the PlioMIP exercise (Contoux et al., 2012). In order to investigate the sensitivity of ice inception to both atmospheric $\mathrm{CO}_{2}$ and orbital parameters, five climate simulations are carried out for group 1: two of them use preindustrial insolation (i.e. the same insolation as used in the PlioMIP exercise) and either $405 \mathrm{ppm}$ (PlioMIP value) or an intermediate value of $360 \mathrm{ppm}$ of $\mathrm{CO}_{2}$ (Table 1). The three other simulations use the minimum summer solstice insolation at $65^{\circ} \mathrm{N}$ occurring during the mid-Piacenzian warm period (Fig. 1) and either 405, 360 or $280 \mathrm{ppm}$ of $\mathrm{CO}_{2}$. For group 2, which aims at 
investigating the possibility to sustain an ice sheet during warmer periods of the Pliocene, the climate model is forced with the ice sheet simulated in the Plio_noice_min_280 experiment, which corresponds to the largest ice sheet 245 simulated during group 1. Three experiments are carried out for group 2: the first two are forced with preindustrial insolation, and either 360 or 405 ppm of $\mathrm{CO}_{2}$, while the last one is forced with the maximum summer solstice insolation at $65^{\circ} \mathrm{N}$ occuring during the mid-Piacenzian warm period (Fig. 1) and $405 \mathrm{ppm}$ of $\mathrm{CO}_{2}$. Finally, in order to assess the sensitivity of our re-

250 sults to the absence of coupling between the climate model and the ice sheet model, two experiments investigate the further growth of the ice sheet when a second iteration of cold conditions is carried out (continued growth experiments): two experiments using minimum insolation, and either $360 \mathrm{ppm}$ or $280 \mathrm{ppm}$ are run a second time, using the respective ice sheet simulated by 255 GRISLI during group 1 as a boundary condition. See Tables 1 and 2 for a summary of the boundary conditions for all the experiments. Spin-up times were minimised by starting each climatic simulation from its closest neighbour in terms of boundary conditions. Every climate configuration (groups 1 and 2) ran for at least 250 yrs. Continued growth experiments were run 260 for an additional 50 yrs. Climatological means are made over 20 years.

\subsubsection{For the ice sheet model}

The climate from each simulation with IPSL-CM5A is used to force the GRISLI model. The initial ice sheet condition in GRISLI is always the same as the ice sheet boundary condition in the forcing IPSL-CM5A simulation.

265 The ice sheet then evolves until in steady state with the prescribed climatic forcing. The GRISLI model is run for $50 \mathrm{kyrs}$, but the final volume of the ice sheet is reached after 10 to 15 kyrs. 


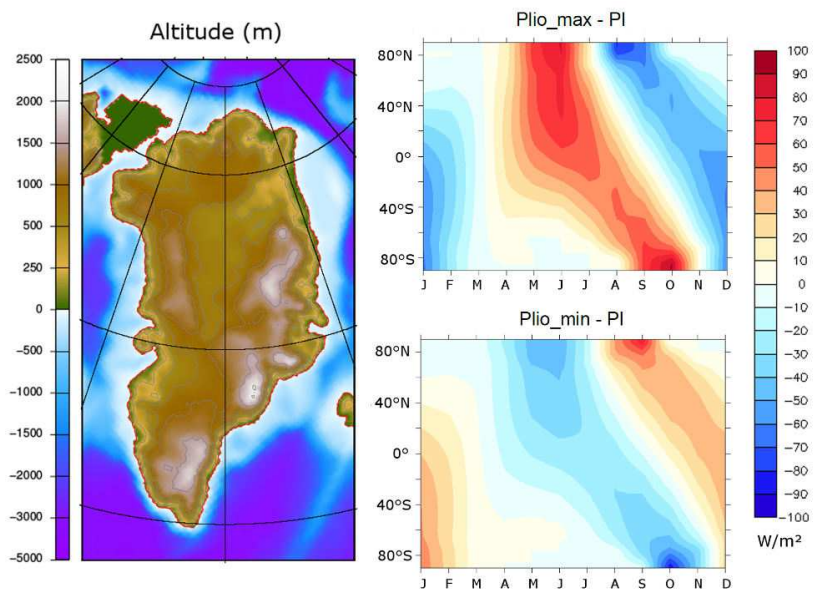

Figure 1: Left: Topography of the deglaciated Greenland corrected for isostasy. Top right: insolation difference between the maximum insolation configuration (Plio_max) and the preindustrial insolation configuration. Bottom right: same for minimum insolation (Plio_min).

\section{Results}

For Plio_noice_PI_405 experiment (i.e. PlioMIP conditions except over

Greenland), only one small ice cap in the SE mountains is simulated by GRISLI (Fig. 2), with a volume representing only $2 \mathrm{~cm}$ of sea level equivalent (Table 3). The surface mass balance is largely negative because of high ablation rates, meaning that the mid-Piacenzian climate obtained with IPSL-CM5A is too warm to allow the build-up of the ice sheet. Even with a lower $\mathrm{CO}_{2}$ value (Plio_noice_PI_360), high ablation rates still largely prevent the build-up of the ice sheet (Fig. 5a,g). The results from Group 1 experiments highlight the difficulty to simulate ice sheet inception with generally accepted $\mathrm{CO}_{2}$ values (360-405 ppm) for the Late Pliocene combined with a moderate insolation pattern (present day). A lower radiative forcing is thus 
needed in order to start ice sheet inception. In this perspective, and given the small response to $\mathrm{CO}_{2}$ decrease alone between 405 and $360 \mathrm{ppm}$, we forced the climate model with minimum insolation together with three different $\mathrm{CO}_{2}$ levels. For Plio_noice_min_405 experiment, two ice caps appear on the highest regions of south Greenland, representing $23 \mathrm{~cm}$ of sea level equivalent (Table 3). They become bigger at 360 ppm (Plio_noice_min_360 experiment, $50 \mathrm{~cm}$ sea level equivalent). At $280 \mathrm{ppm}$, they join and form a small ice sheet going from South Dome to the southeastern Greenland mountains (Plio_noice_min_280 experiment, Fig. 2). This ice sheet inception is possible because of lower summer temperatures, which decrease ablation rates over Greenland (Fig. 5k). However this last simulated ice sheet remains small, with a volume equivalent to $1.2 \mathrm{~m}$ of sea level (Table 3 ).

Even if the Late Pliocene is a period of relatively stable warm conditions, climate variability remains visible in the benthic isotopes record at that time (Lisiecki and Raymo, 2005). It follows that another issue is the possibility of sustaining, during warmer periods, an ice sheet that would have formed during cold periods. We investigate this question with Group 2 experiments using the ice sheet simulated in Plio_noice_min_280 experiment as a boundary condition in the climate model, combined with higher $\mathrm{CO}_{2}$ values typical of Pliocene "interglacials" (360 and 405 ppm, Bartoli et al., 2011) and higher insolation (preindustrial and maximum, see Tables 1 and 2). The resulting ice sheets are shown in Fig. 3. For Plio_ice_PI_360 experiment, the ice sheet barely diminishes in volume and extent (-5\%, Table 3). Even with 405 ppm of $\mathrm{CO}_{2}$, the ice sheet diminishes modestly (Plio_ice_PI_405 experiment, $-22 \%$ in volume). It is only when combining a high $\mathrm{CO}_{2}$ level to high summer insolation that the simulated ice sheet experiences an important melt (Plio_ice_max_405, -77\%). In Group 2, the surface mass balance is still con- 
trolled by high ablation rates over Greenland, but lower ablation rates above the imposed ice sheet (Fig. 5g and i), due to higher topography and higher albedo. Therefore, our simulations suggest that once an ice sheet initiates over southern Greenland, it is sustainable even during warmer periods with higher insolation and higher $\mathrm{CO}_{2}$. Although the topography-surface mass balance feedback is taken into account in the GRISLI model via a lapse rate correction, the ice-albedo feedback is not taken into account with our experimental design, because the climate model is not coupled to the ice sheet model. To assess the impact of this limit, we carried out the Group 3 continued growth experiments. When doing a second iteration, the ice volume largely increases compared to a single iteration (Fig. 4 and Table 3, respectively $+87 \%$ and $+47 \%$ for Plio_ice_min_360 and Plio_ice_min_280 experiments). Nevertheless, the increase in extent is more moderate, especially with $280 \mathrm{ppm}(+28 \%)$, and does not even reach Central Greenland, where ablation rates remain too high (Fig. 5i to f). Accumulation is small outside of the mountain areas, and diminishes in Central Greenland with the presence of an ice sheet (Fig. 5o to r).

\section{Discussion}

\subsection{Towards a cumulative Greenland glaciation}

One of the major contributions of our study is to show the difficulty to form a large ice sheet on Greenland starting from deglaciated or mostly deglaciated conditions. The analysis of accumulation with and without an ice sheet for continued growth experiments (Fig. 5) show that the presence of an ice sheet does not favor more accumulation outside of the ice sheet area. Comparing maps of surface mass balance, accumulation and ablation 
Group 1 experiments : growth
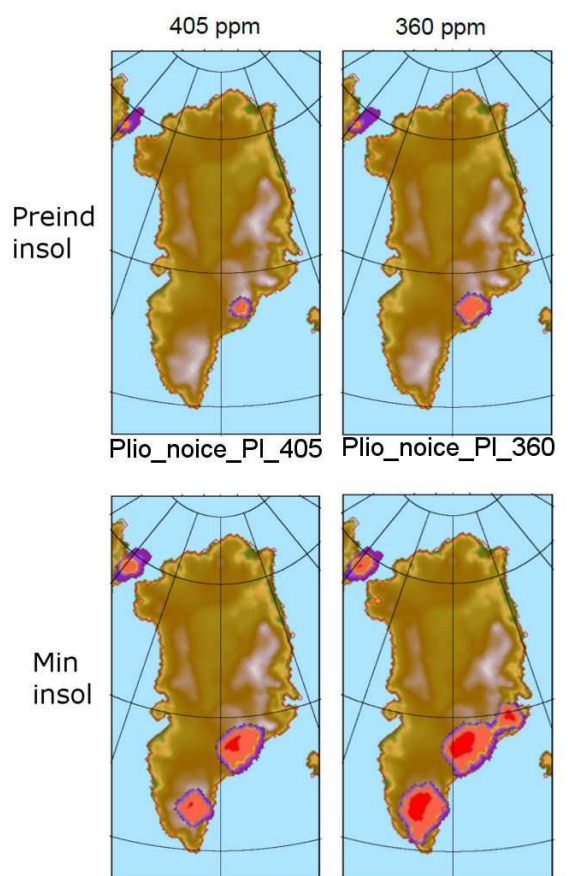

Plio_noice_PI_360
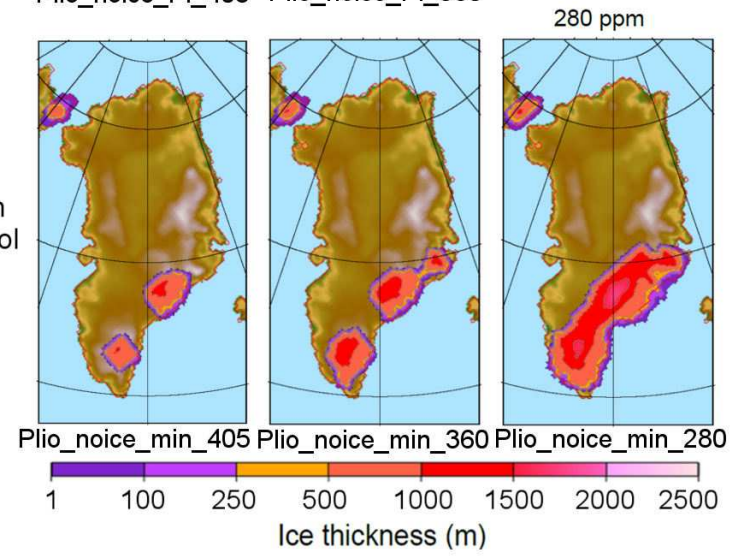

Figure 2: Group 1 experiments (growth). Ice thickness over Greenland simulated with GRISLI starting ice-free, forced with climate from IPSL-CM5A obtained with deglaciated Greenland, preindustrial insolation (top) and minimum insolation (bottom) for 405 (left), 360 (middle) and 280 (right) ppm of $\mathrm{CO}_{2}$. 
Table 3: Simulated Greenland ice sheet volume and its equivalence in sea-level, as well as extent. Percentage of change in volume and extent for simulations starting with an ice sheet. The values are also given for the observed Greenland ice sheet for comparison. The simulation 'ERA-Interim' was carried out by Charbit et al. (2013) using the same version of GRISLI forced by ERA-Interim.

\begin{tabular}{|c|c|c|c|c|c|}
\hline Expt & $\begin{array}{l}\text { GrIS volume } \\
\left(\mathrm{x} 10^{14} \mathrm{~m}^{3}\right)\end{array}$ & $\begin{array}{c}\text { Sea level eq. } \\
(\mathrm{m})\end{array}$ & $\begin{array}{c}\text { Volume change } \\
\text { (\%) }\end{array}$ & $\begin{array}{c}\text { Extent } \\
\left(\mathrm{x} 10^{12} \mathrm{~m}^{2}\right)\end{array}$ & $\begin{array}{r}\text { Extent change } \\
(\%)\end{array}$ \\
\hline Observed & 29 & 7 & - & 1.71 & - \\
\hline ERA-Interim & 31.5 & 7.6 & $+9 \%$ & 1.94 & $+13 \%$ \\
\hline piControl & 35.8 & 8.64 & $+23 \%$ & 2.18 & $+27 \%$ \\
\hline \multicolumn{6}{|c|}{ Group 1 experiments (growth) } \\
\hline Plio_noice_PI_405 & 0.08 & 0.02 & - & 0.013 & - \\
\hline Plio_noice_PI_360 & 0.22 & 0.05 & - & 0.034 & - \\
\hline Plio_noice_min_405 & 0.94 & 0.23 & - & 0.131 & - \\
\hline Plio_noice_min_360 & 2.06 & 0.50 & - & 0.248 & - \\
\hline Plio_noice_min_280 & 5.06 & 1.22 & - & 0.528 & - \\
\hline \multicolumn{6}{|c|}{ Group 2 experiments (melt) } \\
\hline Plio_ice_PI_360 & 4.80 & 1.16 & $-5 \%$ & 0.480 & $-9 \%$ \\
\hline Plio_ice_PI_405 & 3.94 & 0.95 & $-22 \%$ & 0.416 & $-21 \%$ \\
\hline Plio_ice_max_405 & 1.16 & 0.28 & $-77 \%$ & 0.165 & $-69 \%$ \\
\hline \multicolumn{6}{|c|}{ Group 3 experiments (continued growth) } \\
\hline Plio_ice_min_360 & 3.86 & 0.93 & $+87 \%$ & 0.427 & $+72 \%$ \\
\hline Plio_ice_min_280 & 7.45 & 1.80 & $+47 \%$ & 0.675 & $+28 \%$ \\
\hline
\end{tabular}




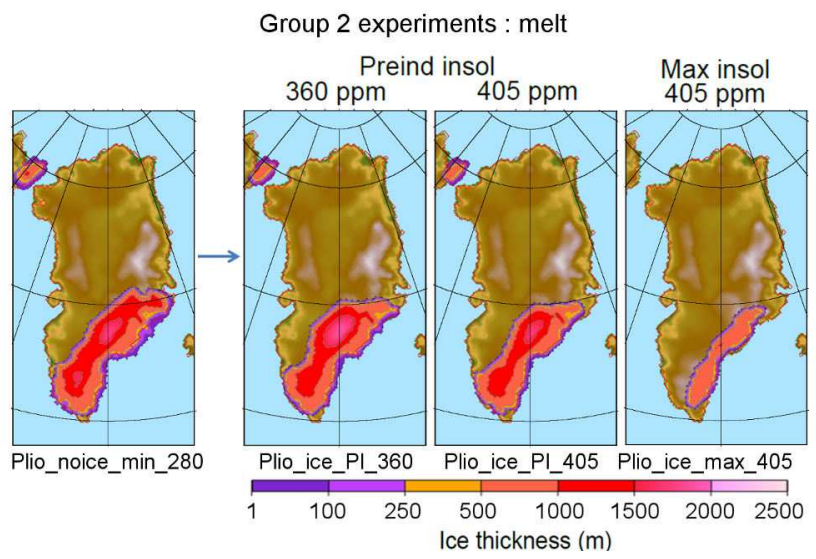

Figure 3: Group 2 experiments (melt). Ice thickness over Greenland simulated with GRISLI starting from Plio_noice_min_280 ice sheet (left), forced with climate from IPSLCM5A obtained with the Plio_noice_min_280 ice sheet and (from second left to right): $360 \mathrm{ppm}$ and preindustrial insolation, $405 \mathrm{ppm}$ and preindustrial insolation, $405 \mathrm{ppm}$ and maximum insolation.

for simulations using the same boundary conditions except ice sheet shows that the presence of an ice sheet induces extra warming in Central Greenland, downwind of the ice sheet, which is seen on the maps by extra ablation and reduced accumulation (see also Ridley et al., 2010; Langen et al., 2012). Thus, although the ice sheet brings a colder temperature reducing ablation on its immediate borders, two effects prevent large ice sheet inception to the north: first, the presence of an ice sheet increases ablation and decreases accumulation in Central Greenland. Second, accumulation rates do not vary much with orbit and $\mathrm{CO}_{2}$ and high values are still located on the southeast, which remains the area of growth of the ice sheet. This result has impacts both for the comprehension of how Greenland fully glaciated during the Late Pliocene, but also for predicting the state of the GrIS in the future. As already suggested by several authors, if Greenland happened to disappear 
Group 3 experiments : continued growth
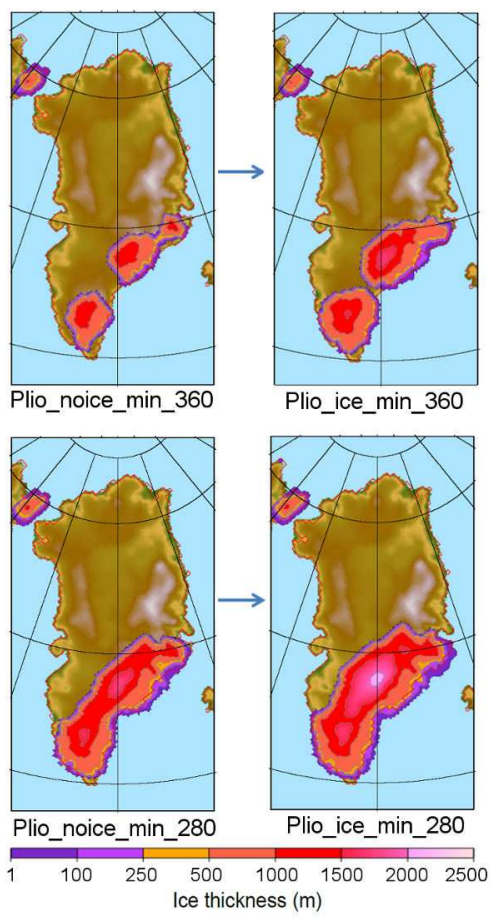

Figure 4: Group 3 experiments (continued growth). Top: Ice thickness over Greenland simulated with GRISLI starting from Plio_noice_min_360 ice sheet (top left), forced with climate from IPSL-CM5A obtained with Plio_noice_min_360 ice sheet, minimum insolation and $360 \mathrm{ppm}$. Bottom: same for GRISLI starting from Plio_noice_min_280 ice sheet (bottom left), forced with climate from IPSL-CM5A obtained with Plio_noice_min_280 ice sheet, minimum insolation and $280 \mathrm{ppm}$. 


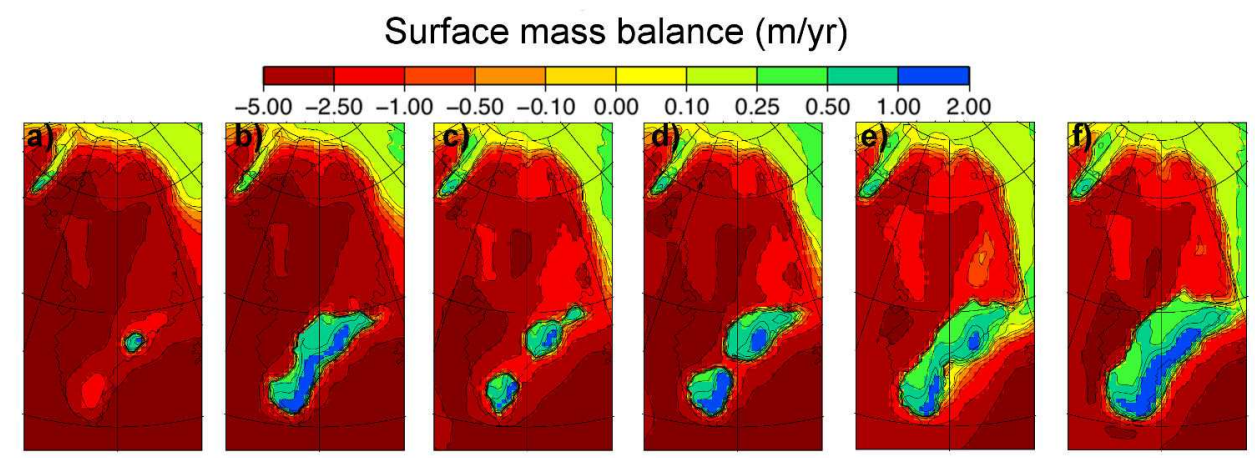

Plio_noice_PI_360 Plio_ice_PI_360 Plio_noice_min_360 Plio_ice_min_360 Plio_noice_min_280 Plio_ice_min_280

Ablation $(\mathrm{m} / \mathrm{yr})$
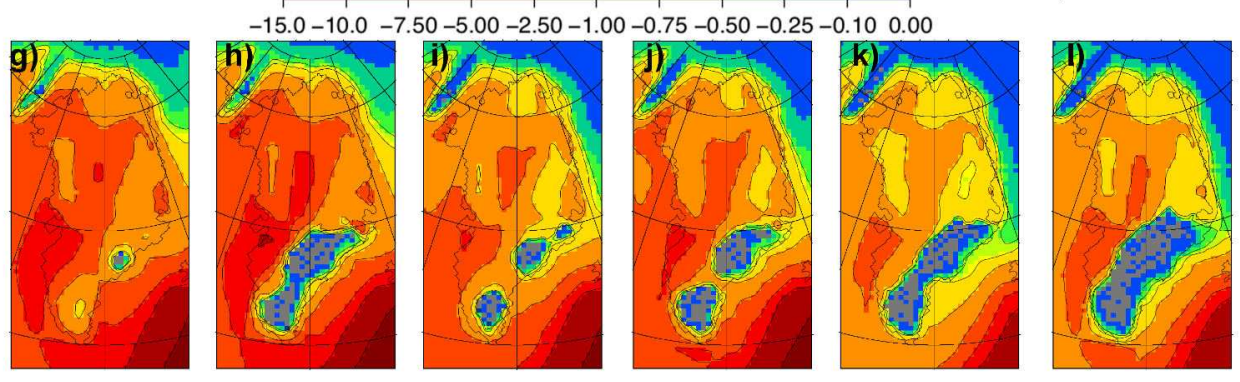

Plio_noice_PI_360

Plio_ice_PI_360 Plio_noice_min_360 Plio_ice_min_360 Plio_noice_min_280 Plio_ice_min_280
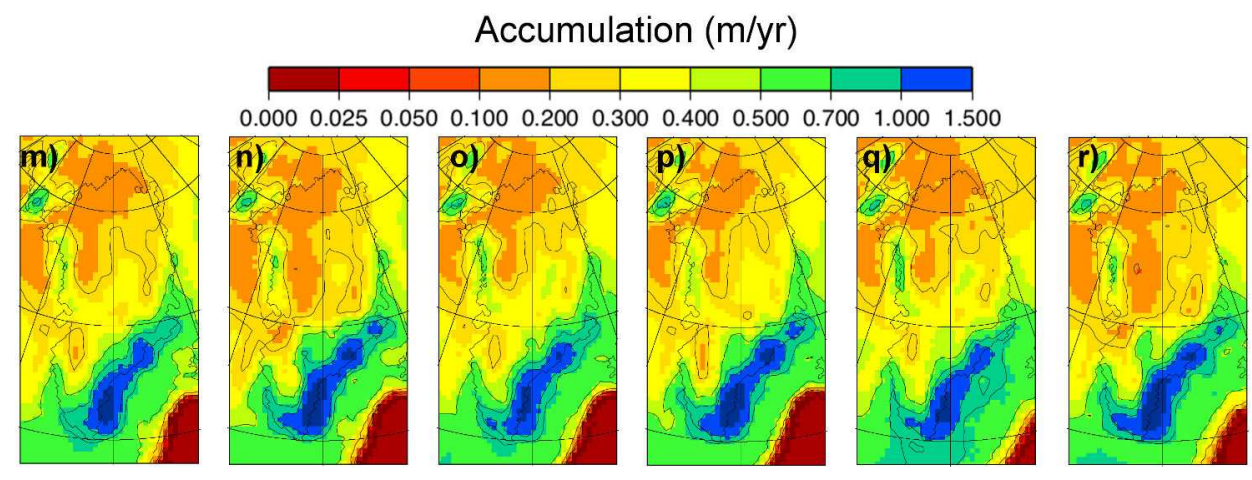

Plio_noice_PI_360 Plio_ice_PI_360 Plio_noice_min_360 Plio_ice_min_360 Plio_noice_min_280 Plio_ice_min_280

Figure 5: Surface mass balance (top), ablation (middle) and accumulation (bottom) simulated with GRISLI, expressed in m.yr ${ }^{-1}$. From left to right: Plio_noice_PI_360 and the corresponding group 2 (melt) experiment Plio_ice_PI_360 ; Plio_noice_min_360 and the corresponding group 3 (continued growth) experiment Plio_ice_min_360 ; Plio_noice_min_280 and the corresponding group 3 (continued growth) experiment Plio_ice_min_280. On ablation panels ( $\mathrm{m}$ to $\mathrm{r}$ ), grey areas correspond to null ablation. 

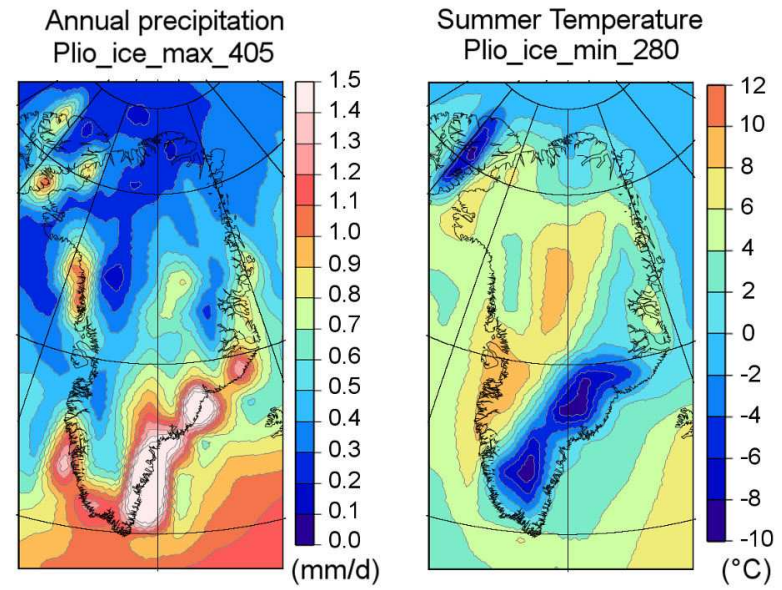

Figure 6: Annual precipitation for the wettest simulation Plio_ice_max_405 (left) and summer temperature (June to August) for the coldest simulation, Plio_ice_min_280.

under present day or warmer conditions, it would very probably not start its regrowth until $\mathrm{CO}_{2}$ reaches back preindustrial values, and only during a low summer insolation period. A pioneering modelling study by Crowley and Baum (1995) demonstrated that if the GrIS entirely melted, it would be impossible to reform with present day boundary conditions. Their study was run with an atmosphere only general circulation model and with low resolution $\left(4.5^{\circ} \times 7.5^{\circ}\right)$ which could not capture the Greenland mountains, thus underestimating the topographic effect over south Greenland. IPSLCM5A is better resolved, but first we use global climate outputs rather than a regional model to force our ice sheet model, and second, as discussed below, glacier inception processes can happen at the sub-kilometer scale, which is not resolved by the ice sheet model. These two aspects are general caveats when reconstructing paleo ice sheets. Toniazzo et al. (2004) also found the melting of the GrIS to be irreversible in preindustrial conditions, 
because of the absence of snow accumulation over deglaciated Greenland in the HadCM3 coupled climate model. These results were contradicted by Lunt et al. (2004), who managed to regrow a significant ice sheet on Greenland in preindustrial climate using the IPSL-CM4 coupled model and a previous version of the GRISLI model, GREMLINS (Ritz et al., 1997). Our study does not prescribe ice free Greenland in preindustrial conditions, thus our results are not directly comparable to Lunt et al. (2004) or Toniazzo et al. (2004). However, accumulation rates over central and North Greenland are very small in our simulations (Fig. 5m to r) due to low precipitation, combined to ablation rates which are 50 times higher, suggesting that a regrowth of the ice sheet over Central Greenland after total melting 370 as Lunt et al. (2004) depicted is not possible with IPSL-CM5A. Summer temperatures are never low enough and prevent the presence of perennial snow in this area even for the coldest simulation (Fig. 6). This impossibility to grow ice on North and Central Greenland is thus driven both by limited amount of precipitation and too high temperatures. When $\mathrm{CO}_{2}$ is reduced, ice volume growth is controlled by ablation reduction (i.e. temperature decrease). Additionally, the presence of an ice sheet seems to prevent growth in Central Greenland by generating warmer temperature downwind through a foehn effect, similarly to Langen et al. (2012). Thus, when taking a minimum insolation and low estimates of $\mathrm{CO}_{2}$ for this period, it is not possible to reproduce either the PRISM2 or PRISM3 ice sheets, in terms of volume but also of location, and finally, it is not possible to widely glaciate Greenland. This result is in agreement with Born and Nisancioglu (2012) who show that the northern Greenland ice sheet is the most sensitive to warming during the Eemian given the very low accumulation rates in this area. In addition, we show that the steady state volume and location of the 
Pliocene GrIS simulated with GRISLI forced by IPSL-CM5A is dependent on the GrIS boundary condition in the climate model (starting ice free or from PRISM3 ice sheet), meaning that the initial GrIS condition in the climate model is very important (see also Abe-Ouchi and Blatter, 1993). By starting deglaciated rather than half glaciated, we cannot grow a big ice sheet on climate, contrary to Lunt et al. (2008) or Dolan et al. (2011). This shows the importance of characterizing the GrIS during the Late Pliocene for studying the causes of the Northern Hemisphere Glaciation at the PlioPleistocene boundary. In Koenig et al. (2011), full glaciation is obtained from deglaciated conditions using 200 ppm of $\mathrm{CO}_{2}$ and low summer insolation in a coupled climate-vegetation-ice sheet model. In Lunt et al. (2008), full glaciation is reached with a higher value of $280 \mathrm{ppm}$ of $\mathrm{CO}_{2}$, because the imposed ice sheet in the climate model is already half the volume of the present day one, and covers approximately a third of Greenland's surface. Although both these studies are pioneering because they demonstrate the major role of the $\mathrm{CO}_{2}$ drop compared to other tectonic/climatic factors (Lunt et al., 2008) and the additional role of vegetation feedbacks (Koenig et al., 2011) on Greenland glaciation, they are not fully satisfactory because they use unrealistic boundary conditions. $\mathrm{A} \mathrm{CO}_{2}$ value of $200 \mathrm{ppm}$ is too 405 low for the Late Pliocene (e.g. Badger et al., 2013), and the presence of an ice sheet over Central Greenland during that time is disputable (e.g. Bierman et al., 2014). Despite our methodology also has drawbacks, we have demonstrated that although a $\mathrm{CO}_{2}$ drop to $280 \mathrm{ppm}$ is crucial, it is not sufficient to lead to full glaciation during the Late Pliocene if we assume 410 a more realistic ice sheet distribution in our climate model. Our results rather suggest that the full glaciation over Greenland must have been a slow, backward and forward process because of change in insolation, pro- 
gressively accumulating snow and ice during low summer insolation times with the decrease in $\mathrm{CO}_{2}$. This scenario emphasizes the role of ice sheet feedbacks (both topography-surface mass balance and ice-albedo feedbacks) for sustaining some ice during high summer insolation times, and allowing further accumulation during low summer insolation periods. In addition, the limited amount of precipitation in Central and North Greenland does not allow a fast-growth scenario after reaching a critical GrIS mass. When an ice sheet begins to form, these regions get even warmer due to the foehn effect (Langen et al., 2012). We thus suggest that the full coverage of Greenland happens progressively through accumulation in the Southeast during cold periods, and also during wetter and mildly warmer periods, when precipitation penetrates more northward into Greenland. Indeed, although the

425 Plio_ice_PI_360 ice sheet experiences an overall melt, it extent has grown slightly towards the west in its southern part (Fig. 3).

\subsection{Model dependency and biases}

Ice sheet model. The simulated ice sheet depends on the surface mass balance calculation in the ice sheet model used, although much less than on the climate model used (Koenig et al., 2015). If GRISLI is forced with observations (ERA-Interim as in Charbit et al., 2013), the simulated Greenland volume is $3.15 \times 10^{15} \mathrm{~m} 3$, i.e. $9 \%$ bigger than the observed volume. GRISLI $40 \mathrm{~km}$ does not allow a correct representation of ice streams, which leads to a slight overestimation of the simulated ice sheet volume. This is in addition amplified by the cold bias in IPSL-CM5A PI simulation. Nevertheless, this GRISLI bias towards larger simulated ice sheet is not so problematic for our study for several reasons. First, ice dynamics are not important for the initiation of ice sheets. Surface mass balance is driven by IPSL simu- 
lated climatology, and by the PDD formula. Second, ice streams are a key parameter mostly for large ice sheets. Because we simulate very small ice sheets for all the Pliocene configurations, bad resolution of ice streams will have only minor impacts on our results. Finally, the PDD formula and ice dynamics resolution in GRISLI all lead to an overestimation of simulated ice volume. However, the simulated ice volume remains small in the Pliocene simulations, strengthening our idea that full glaciation cannot be a single event.

Climate model. Even if the IPSL-CM5A model depicts consistent skills to simulate the climate on Greenland for the present and recent paleoclimates, different climate models using the same Pliocene PRISM3 boundary conditions simulate a vast range of climates over Greenland. These different simulated climates lead to different simulated ice sheets, highlighting the climate model dependency of simulated ice sheets (Dolan et al., 2015). This is also true for the Antarctic Ice Sheet, for example during the Eocene (Gasson et al., 2014). Nevertheless, the GrIS simulated with BASISM using climate outputs of the IPSL-CM5A model is comparable to the GrIS simulated with the HadCM3 and GISS models, and does not vary much from the imposed initial ice sheet (PRISM3) (Dolan et al., 2015). In addition to ice sheet model bias, the simulated volume for the preindustrial simulation is too big because of a cold bias in the IPSL-CM5A preindustrial simulation, both on Greenland and on the North Atlantic (Dufresne et al., 2013; Hourdin et al., 2013). The existence of this cold bias for Pliocene simulations cannot be assessed.

Resolution. The coarse resolution of both the AOGCM and the ice sheet model could lead to underestimation of the response of the ice sheet to ex- 
ternal forcings such as insolation or $\mathrm{CO}_{2}$, rendering the ice inception/growth and also deglaciation more difficult to simulate. The climate model has a resolution of $2.5^{\circ} \times 1.875^{\circ}$. This will have a strong impact on the simulated ablation and accumulation at the ice sheet margins, where temperature and precipitation gradients can be important (Ridley et al., 2010). Additionally, the $40 \mathrm{~km}$ grid size for the GRISLI ice sheet model could be too rough to correctly resolve the inception of the GrIS on the Eastern mountain range of Greenland (Abe-Ouchi and Blatter, 1993). Taking into account sub-grid scale topography could potentially help to grow more ice, although this effect is more important in mountainous regions where an ice sheet already exists (Marshall and Clarke, 1999).

\subsection{Limits of our methodology}

Although to force an ice sheet model with climate model outputs is a method widely used in paleoclimate studies, a number of processes are not taken into account, which mostly imply that the $\mathrm{CO}_{2}$ level leading to inception is underestimated, and conversely is overestimated for deglaciation. In particular, many studies demonstrate that the replacement of boreal forest by tundra was a powerful positive feedback to further enhance glaciation (e.g. Khodri et al., 2001; Koenig et al., 2011). Interactive vegetation could favor larger glaciation when insolation is low, amplifying the direct radiative impact of orbital changes, through albedo (Koenig et al., 2011). In our study, interactive vegetation could increase the ice sheet volume via temperature feedbacks if evergreen taiga was changed to tundra, but would probably not help to build up an ice sheet over central or northern Greenland, where the limiting factor is not only temperature, but also precipitation, 490 which is reduced with tundra replacing taiga (Koenig et al., 2011). An- 
other study (Stone and Lunt, 2013) shows that in a preindustrial climate with deglaciated Greenland, including vegetation feedbacks only leads to a small growth in the regions of high topography. In addition, our methodology does not include ice-albedo feedback, although it takes into account the elevation-surface mass balance feedback via the lapse rate correction in GRISLI. The impact of including a previous ice sheet is assessed with the Group 3 experiments (continued growth). The analysis of accumulation with and without an ice sheet for continued growth experiments (Fig. 5) show that the ice sheet decreases the surface mass balance on Central Greenland. Thus, although the ice sheet brings a conducive temperature reducing ablation, high accumulation rates are still located on the southeast, which remains the area of growth of the ice sheet. This means that a full coupling of IPSL-CM5A and GRISLI could probably manage to glaciate more the southeast mountains and south dome, but the global picture of accumulation and ablation areas would remain the same, and we would not reach temperatures low enough to abruptly glaciate central Greenland. However, the absence of interactive ice-albedo feedback leads to an underestimation of the $\mathrm{CO}_{2}$ threshold leading to inception, as well as an overestimation of the $\mathrm{CO}_{2}$ threshold leading to a deglaciation (Ridley et al., 2010; Abe-Ouchi 510 et al., 2013; Ladant et al., 2014). Abe-Ouchi and Blatter (1993) have shown that in order to build a large ice sheet, positive surface mass balance must be accompanied a sufficiently large accumulation rate. If the accumulation rate remains small, as in our study, even though surface mass balance is positive, the steady-state ice sheet will only reach the small ice cap solution.

515 Finally, it is important to keep in mind that because we do not use a coupled climate-ice sheet model, the simulated ice sheets are not representative of real ice sheets, in full equilibrium with the real world climate forcings, which 
also vary with time. Because of that caveat and the fact that the forcing do not vary in our simulations, it is impossible for us to assess the transient response of the ice sheet to real world, varying forcings. Several studies have tackled this issue and investigated the hysteresis of the ice sheets by using asynchronously coupled climate ice sheet models (e.g. Pollard and DeConto, 2005; Abe-Ouchi et al., 2013).

\section{Conclusions and outlook}

525 Although our methodology underestimates the $\mathrm{CO}_{2}$ threshold leading to glaciation, we show that a drop in $\mathrm{CO}_{2}$ at the end of the Pliocene is not sufficient to lead to a large scale glaciation over Greenland, when imposing a more realistic Greenland ice sheet boundary condition in IPSL-CM5A. We do not manage, with GRISLI forced offline by climate from IPSL-CM5A, to simulate a large Pliocene ice sheet on Greenland even with low $\mathrm{CO}_{2}$ and the most favourable orbital conditions, even including a previously simulated ice sheet (continued growth simulations). The simulated ice sheet is restricted to southeast Greenland, because the North and Central parts experience high ablation combined with limited accumulation. Consequently, it is not possible to reproduce either the PRISM2 or PRISM3 ice sheets. This result corroborates the findings of Koenig et al. (2015), highlighting the necessity to redefine the GrIS boundary condition to a southeast located ice sheet for future Pliocene climate studies. The fact that central Greenland remains ice free during the Late Pliocene is confirmed by a recent study by Bierman et al. (2014) which claims that this part was deglaciated during 200 kyrs to 1 Myr before the glaciation at 2.7 Ma, i.e. probably since the anomalous glaciation of MIS M2 at 3.3 Ma. The limited amount of precipitation in 
Central and North Greenland does not allow a scenario of fast growth after reaching a critical GrIS mass. When an ice sheet begins to form, these reresults also suggest that if Greenland happened to disappear under present day or warmer conditions, it could be unable to start its regrowth until $\mathrm{CO}_{2}$ reaches back preindustrial values. Because we do not have a coupled climate-ice sheet model, our results give an indication of what could be the not allow to know the final state, equilibrium ice sheet, unlike full coupled climate-ice sheet models or recoupling methods such as in Ladant et al. (2014). With our method, a fast growth scenario is not possible but since albedo feedback is not taken into account, there is an uncertainty on the toGreenland Ice Sheet formation (not including the MIS M2 which could be controlled by external factors) that cannot be captured by snapshot model experiments as used in this study, but would require transient coupled climate ice sheet modelling.

\section{Acknowledgements}

C. Contoux thanks D. Paillard for fruitful discussions and for providing Analyseries (Paillard et al., 1996), Y. Donnadieu for useful advice, P. Beghin 
for technical help, and D. Coppin for his participation in the very early stage of this work. A.M. Dolan acknowledges funding from the European Re(FP7/2007-2013) / ERC grant agreement number 278636 and NERC for the provision of a doctoral training grant. The work of C. Contoux was performed using HPC resources from GENCI - [CCRT/TGCC/CINES/IDRIS] (Grant 2013- GEN2212). The comments of two anonymous reviewers greatly 575 improved the earlier version of the manuscript.

\section{References}

Abe-Ouchi, A., Blatter, H.: On the initiation of ice sheets, Annals of Glaciology, 18, 203-207, 1993.

Abe-Ouchi, A., Saito, F., Kawamura, K., Raymo, M. E., Okuno, J., Takahashi, K., Blatter, H.: Insolation-driven 100,000-year glacial cycles and hysteresis of ice-sheet volume, Nature, 500, 190-193, doi:10.1038/nature12374, 2013.

Arakawa, A. and Lamb, V. R.: A potential enstrophy and energy conserving scheme for the shallow water equations. Mon. Wea. Rev., 109 (1), 18-36, 585

Badger, M. P., Schmidt, D. N., Mackensen, A., Pancost, R. D.: Highresolution alkenone palaeobarometry indicates relatively stable pCO2 during the Pliocene (3.32.8 Ma), Philosophical Transactions of the Royal Society A: Mathematical, Physical and Engineering Sciences, 371, 20130094, 590 2013. 
Bartoli, G., Hönisch, B., and Zeebe, R. E.: Atmospheric CO2 decline during the Pliocene intensification of Northern Hemisphere glaciations, Paleoceanography, 26, PA4213, doi:10.1029/2010PA002055, 2011.

Beghin, P., Charbit, S., Dumas, C., Kageyama, M., Roche, D. M., and Ritz, C.: Interdependence of the growth of the Northern Hemisphere ice sheets during the last glaciation: the role of atmospheric circulation, Clim. Past, 10, 345-358, doi:10.5194/cp-10-345-2014, 2014.

Beghin, P., Charbit, S., Kageyama, M., Dumas, C., and Ritz, C.: How might the North American ice sheet influence the Northwestern Eurasian climate?, Clim. Past Discuss., 11, 27-61, doi:10.5194/cpd-11-27-2015, 2015.

Berger, A., Li, X.S. and Loutre, M.-F.: Modelling northern hemisphere ice volume over the last 3 Ma, Quaternary Science Reviews, 18, 1-11, 1999.

Bierman, P. R., Corbett, L. B., Graly, J. A., Neumann, T. A., Lini, A., Crosby, B. T., Rood, D. H.: Preservation of a Preglacial Landscape Under the Center of the Greenland Ice Sheet, Science Reports, doi:10.1126/science.1249047, 2014.

Brigham-Grette, J., Melles, M., Minyuk, P., Andreev, A., Tarasov, P., DeConto, R., Koenig, S., Nowaczyk, N., Wennrich, V., Rosen, P., Haltia, E., Cook, T., Gebhardt, C., Meyer-Jacob, C., Snyder, J., Herzschuh, U.: Pliocene Warmth, Polar Amplification, and Stepped Pleistocene Cooling Recorded in NE Arctic Russia, Science, 340, 1421-1427, 2013.

Bonelli, S., Charbit, S., Kageyama, M., Woillez, M.-N., Ramstein, G., Dumas, C., and Quiquet, A.: Investigating the evolution of major Northern 
Hemisphere ice sheets during the last glacial-interglacial cycle, Clim. Past, $5,329345,2009$.

Born, A., Nisancioglu, K. H.: Melting of Northern Greenland during the last interglaciation, The Cryosphere, 6, 1239-1250, 2012.

Charbit, S., Dumas, C., Kageyama, M., Roche, D. M. and Ritz, C.: Influence of ablation-related processes in the build-up of simulated Northern Hemisphere ice sheets during the last glacial cycle, The Cryosphere, 7, 681-698, 2013.

Contoux, C., Ramstein, G., and Jost, A.: Modelling the mid-Pliocene Warm Period climate with the IPSL coupled model and its atmospheric component LMDZ5A, Geosci. Model Dev., 5, 903-917, doi:10.5194/gmd-5-903$2012,2012$.

Contoux, C., Jost, A., Ramstein, G., Sepulchre, P., Krinner, G. and Schuster, M.: Megalake Chad impact on climate and vegetation during the late Pliocene and the mid-Holocene. Clim. Past, 9, 1417-1430, 2013.

Cravatte, S., Madec, G., Izumo, T., Menkes, C. and Bozec A.: Progress in the 3-D circulation of the eastern equatorial Pacific in a climate ocean model. Ocean Model., 17, 28-48, doi:10.1016/j.ocemod.2006.11.003, 2007.

Crowley, T. J., and Baum, S. K.: Is the Greenland ice sheet bistable?, Paleoceanography, 10, 357-363, 1995.

De Schepper, S., Head, M. J. and Groeneveld, J.: North Atlantic Current variability through marine isotope stage M2 (circa 3.3 Ma) during the mid-Pliocene, Paleoceanography, 24, PA4206, doi:10.1029/2008PA001725, 2009. 
De Schepper, S., Groeneveld, J., Naafs, B.D.A., Van Renterghem, C., Hennissen, J., Head, M.J., Louwye, S., Fabian, K.: Northern Hemisphere glaciation during the globally warm early Late Pliocene, PLoS ONE 8, e81508, doi:10.1371/journal.pone.0081508, 2013.

De Schepper, S., Gibbard, P. L., Salzmann, U., Ehlers, J.: A global synthesis of the marine and terrestrial evidence for glaciation during the Pliocene Epoch, Earth Science Reviews, doi: 10.1016/j.earscirev.2014.04.003, in press.

Dolan, A. M., Haywood, A. M., Hill, D. J., Dowsett, H. J., Hunter, S. J., Lunt, D. J. and Pickering, S.: Sensitivity of Pliocene ice sheets to orbital forcing, Palaeogeogr. Palaeocl., 309, 98-110, 2011.

Dolan, A. M., Koenig, S. J., Hill, D. J., Haywood, A. M., DeConto, R. M.: Pliocene Ice Sheet Modelling Intercomparison Project (PLISMIP) experimental design, Geosci. Model Dev., 5, 963-974, 2012.

Dolan, A. M., Hunter, S. J., Hill, D. J., Haywood, A. M., Koenig, S. J., Otto-Bliesner, B. L., Abe-Ouchi, A., Bragg, F., Chan, W.-L., Chandler, M. A., Contoux, C., Jost, A., Kamae, Y., Lohmann, G., Lunt, D. J., Ramstein, G., Rosenbloon, N. A., Sohl, L., Stepanek, C., Ueda, H., Yan, Q., Zhang, Z.: Using results from the PlioMIP ensemble to investigate the Greenland Ice Sheet during the mid-Pliocene Warm Period, Clim. Past, 11, 403-424, doi:10.5194/cp-11-403-2015, 2015.

Dowsett, H.J., Barron, J.A., Poore, R.Z., Thompson, R.S., Cronin, T.M., ${ }_{660}$ Ishman, S.E., and Willard, D.A.: Pliocene Paleoenvironmental Reconstruction: U.S. Geological Survey Open File Report, 99-535, 1999. 
Dowsett, H. J., Robinson, M. M., and Foley, K. M.: Pliocene threedimensional global ocean temperature reconstruction, Clim. Past, 5, 769$783,2009$.

Dowsett, H. J., Foley, K. M., Stoll, D. K., Bentsen, M., Otto-Bliesner, B. L., Bragg, F. J., Chan, W.-L., Chandler, M. A., Contoux, C., Dolan, A., Haywood, A., Jonas, J. A., Jost, A., Kamae, Y., Lohmann, G., Lunt, D. J., Nisancioglu, K. H., Abe-Ouchi, A., Ramstein, G., Riesselman, C. R., Robinson, M. M., Rosenbloom, N. A., Salzmann, U., Sohl, L., Stepanek, C., Strother, S. S., Ueda, H., Ying, Q. and Zhang, Z.: Sea surface temperature of the mid-Piacenzian ocean: a data-model comparison. Nature Scientific Reports, 3, 2013, doi:10.1038/srep02013, 2013.

Dufresne, J-L, Foujols, M-A., Denvil, S., Caubel, A., Marti, O. Aumont, O., Balkanski, Y., Bekki, S., Bellenger, H., Benshila, R., Bony, S., Bopp, L., Braconnot, P., Brockmann, P., Cadule, P., Cheruy, F., Codron, F., Cozic, A., Cugnet, D., de Noblet, N., Duvel, J.-P., Eth, C., Fairhead, L., Fichefet, T., Flavoni, S., Friedlingstein, P., Grandpeix, J.-Y., Guez, L., Guilyardi, E., Hauglustaine, D., Hourdin, F., Idelkadi, A., Ghattas, J., Joussaume, S., Kageyama, M., Krinner, G., Labetoulle, S., Lahellec, A., Lefebvre, M.P., Lefevre, F., Levy, C., Li, Z.-X., Lloyd, J., Lott, F., Madec, G., Mancip, M., Marchand, M., Masson, S., Meurdesoif, Y., Mignot, J., Musat, I., Parouty, S., Polcher, J., Rio, C., Schulz, M, Swingedouw, D., Szopa, S., Talandier, C., Terray, P. and Viovy, N.: Climate change projections using the IPSL-CM5 Earth System Model: from CMIP3 to CMIP5, Clim. Dynam., 40, 2123-2165, 2013.

Dwyer, G. S., Chandler, M. A.: Mid-Pliocene sea level and continental ice 
volume based on coupled benthic $\mathrm{Mg} / \mathrm{Ca}$ palaeotemperatures and oxygen isotopes. Philosophical Transactions of the Royal Society A: Mathematical, Physical and Engineering Sciences, 367, 157-168, 2009.

Fausto, R. S., Ahlstrom, A. P., van As, D., Johnsen, S. J., Langen, P. L., and Steffen, K.: Improving surface boundary conditions with focus on coupling snow densification and meltwater retention in large-scale ice-sheet models of Greenland, J. Glaciol., 55, 869-878, 2009.

Fichefet, T. and Morales-Maqueda, M. A.: Sensitivity of a global sea ice model to the treatment of ice thermodynamics and dynamics, J. Geophys. Res., 102 (C6), 12,609-12,646, doi:10.1029/97JC00480, 1997.

Fichefet, T. and Morales-Maqueda, M. A.: Modelling the influence of snow accumulation and snow-ice formation on the seasonal cycle of the Antarctic sea-ice cover, Clim. Dyn., 15, 251-268, doi:10.1007/s003820050280, 1999.

Gasson, E., Lunt, D. J., DeConto, R., Goldner, A., Heinemann, M., Huber, M., LeGrande, A. N., Pollard, D., Sagoo, N., Siddall, M., Winguth, A., and Valdes, P. J.: Uncertainties in the modelled CO2 threshold for Antarctic glaciation, Clim. Past, 10, 451-466, doi:10.5194/cp-10-451-2014, 2014 .

Haywood, A. M., Dowsett, H. J., Otto-Bliesner, B., Chandler, M. A., Dolan, A. M., Hill, D. J., Lunt, D. J., Robinson, M., Rosenbloom, N., Salzmann, U., and Sohl, L. E.: Pliocene Model Intercomparison Project (PlioMIP): experimental design and boundary conditions (Experiment 1), Geosci. Model Dev., 3, 227-242, doi:10.5194/gmd-3-227-2010, 2010. 
Haywood, A. M., Dowsett, H. J., Robinson, M. M., Stoll, D. K., Dolan, A. M., Lunt, D. J., Otto-Bliesner, B., and Chandler, M. A.: Pliocene Model Intercomparison Project (PlioMIP): experimental design and boundary conditions (Experiment 2), Geosci. Model Dev., 4, 571-577, doi:10.5194/gmd-4-571-2011, 2011.

Haywood, A. M., Hill, D. J., Dolan, A. M., Otto-Bliesner, B. L., Bragg, F., Chan, W.-L., Chandler, M. A., Contoux, C., Dowsett, H. J., Jost, A., Kamae, Y., Lohmann, G., Lunt, D. J., Abe-Ouchi, A., Pickering, S. J., Ramstein, G., Rosenbloom, N. A., Salzmann, U., Sohl, L., Stepanek, C., Ueda, H., Yan, Q., and Zhang, Z.: Large-scale features of Pliocene climate: results from the Pliocene Model Intercomparison Project, Clim. Past, 9, 191-209, doi:10.5194/cp-9-191-2013, 2013.

Haywood, A. M., Dolan, A. M., Pickering, S. J., Dowsett, H. J., McClymont, E. L., Prescott, C. L., Salzmann, U., Hill, D. J., Hunter, S. J., Lunt, D. J., Valdes, P. J.: On the identification of a Pliocene time slice for data-model comparison. Philosophical Transactions of the Royal Society A, 371, 2001, 2013.

Hill, D. J.: Modelling Earth's Cryosphere during Pliocene Warm Peak, Ph.D. thesis, University of Bristol, UK, 368 pp, 2009.

Hill, D. J., Haywood, A. M., Hindmarsh, R. C. A., and Valdes, P. J. Characterising ice sheets during the mid-Pliocene: evidence from data and models, In: Deep Time Perspectives on Climate Change: Marrying the Signal from Computer Models and Biological Proxies, edited by: Williams, M., Haywood, A. M., Gregory, F. J. and Schmidt, D. H., Micropalaeontol. 735 Soc., Spec. Pub. Geol. Soc., London, 517-538, 2007. 
Hill, D.J., Dolan, A.M., Haywood, A.M., Hunter, S.J., Stoll, D.K.: Sensitivity of the Greenland Ice Sheet to Pliocene sea surface temperatures, Stratigraphy, 7, 111-122, 2010.

Hourdin F., Foujols, M.-A., Codron, F., Guemas, V., Dufresne, J.-L., Bony, S., Denvil, S., Guez, L., Lott, F., Ghattas, J., Braconnot, P., Marti, O., Meurdesoif, Y., Bopp, L.: Impact of the LMDZ atmospheric grid configuration on the climate and sensitivity of the IPSL-CM5A coupled model, Clim. Dynam., 40, 2167-2192, 2013.

Jansen, E., Fronval, T., Rack, F., Channell, J. E.: Pliocene-Pleistocene ice rafting history and cyclicity in the Nordic Seas during the last $3.5 \mathrm{Myr}$, Paleoceanography, 15, 709-721, 2000.

Japsen, P., Bonow, J.M., Green, P.F., Chalmers, J.A., Lidmar-Bergström, K.: Elevated, passive continental margins: long-term highs or Neogene uplifts? New evidence from West Greenland,. Earth Planet. Sci. Lett. 248, 330-339, 2006.s

Kageyama M., Braconnot, P., Bopp, L., Mariotti, V., Roy, T., Woillez, M.N., Caubel, A., Foujols, M.-A., Guilyardi, E., Khodri, M., Lloyd, J., Lombard, F., Marti, O.: Mid-Holocene and Last Glacial Maximum climate simulations with the IPSL model: part 2: model-data comparisons, Clim. Dynam., doi:10.1007/s00382-012-1499-5, 40, 2469-2495, 2013.

Kleiven, H. F., Jansen, E., Fronval, T., Smith, T. M.: Intensification of Northern Hemisphere glaciations in the circum Atlantic region (3.52.4 Ma)ice-rafted detritus evidence, Palaeogeography, Palaeoclimatology, Palaeoecology, 184, 213-223, 2002. 
Khodri, M., Leclainche, Y., Ramstein, G., Braconnot, P., Marti, O., Cortijo, E.: Simulating the amplification of orbital forcing by ocean feedbacks in the last glaciation, Nature, 410, 570-574, 2001.

Koenig, S., DeConto, R., and Pollard, D.: Late Pliocene to Pleistocene sensitivity of the Greenland Ice Sheet in response to external forcing and internal feedbacks, Clim. Dyn., 37, 1247-1268, doi:10.1007/s00382- 0111050-0, 2011.

Koenig, S., Dolan, A. M., de Boer, B., Stone, E. J., Hill, D. J., DeConto, R. M., Abe-Ouchi, A., Lunt, D. J., Pollard, D., Quiquet, A., Saito, F., Savage, J. and van de Wal, R.: Ice sheet model dependency of the simulated Greenland Ice Sheet in the mid-Pliocene, Clim. Past, 11, 369-381, doi:10.5194/cp-11-369-2015, 2015.

Ladant, J.-B., Donnadieu, Y., Lefebvre, V., Dumas, C.: The respective role of atmospheric carbon dioxide and orbital parameters on ice sheet evolution at the Eocene-Oligocene transition, Paleoceanography, 29, doi:10.1002/2013PA002593, 2014.

Laskar, J., Robutel, P., Joutel, F., Gastineau, M., Correia, A.C.M., Levrard, B.: A long-term numerical solution for the insolation quantities of the Earth, Astronomy and Astrophysics, 428, 261-285, 2004.

Langen, P. L., Solgaard,A. M., Hvidberg, C. S.: Self-inhibiting 780 growth of the Greenland Ice Sheet, Geophy. Res. Lett., 39, L12502, doi:10.1029/2012GL051810, 2012.

Le Meur, E., Huybrechts, P.: A comparison of different ways of dealing with 
isostasy: Examples from modelling the Antarctic ice sheet during the last glacial cycle, Ann. Glaciol., 23, 309-317, 1996.

Le Sommer, J., Penduff, T., Theetten, S., Madec, G., and Barnier., B.: How momentum advection schemes influence current-topography interactions at eddy permitting resolution. Ocean Model., 29 (1), 1-14, doi:10.1016/j.ocemod.2008.11.007, 2009.

Leduc, G., Garbe-Schönberg, D., Regenberg, M., Contoux, C., Etourneau, J. et Schneider, R.: The Late Pliocene Benguela upwelling status revisited by means of multiple temperature proxies, Geochem. Geophy. Geosy.,15, 475491, doi:10.1002/2013GC004940, 2014.

Letréguilly, A., Huybrechts, P., Reeh, N.: Steady-state characteristics of the greenland ice sheet under different climates, J. Glaciol., 37, 149-157, 1991. for biogeochemical models. Geophys. Res. Lett., 28 (19), 3725-3728, doi:10.1029/2001GL012947, 2001.

Lisiecki, L. E. and Raymo, M. E.: A Pliocene-Pleistocene stack of 57 globally distributed benthic d18O records, Paleoceanography, 20, PA1003, 10.1029/2004PA001071, 2005.

Lott, F.: Alleviation of Stationary Biases in a GCM through a Mountain Drag Parameterization Scheme and a Simple Representation of Mountain Lift Forces, Mon. Wea. Rev., 127, 788-801, 1999.

Lunt, D. J., de Noblet-Ducoudré N., Charbit, S.: Effects of a melted Green805 land ice sheet on climate, vegetation, and the cryosphere, Clim. Dynam., 23, 679-694, 2004. 
Lunt, D. J., Foster, G. L., Haywood, A. M., and Stone, E. J.: Late Pliocene Greenland glaciation controlled by a decline in atmospheric CO2 levels, Nature, 454, 1102-1106, 2008.

MacAyeal, D. R.: Large-scale ice flow over a viscous basal sediment: theory and application to ice stream B, Antarctica, J. Geophys. Res., 94, 40714087, 1989.

Madec, G.: NEMO ocean engine. Technical note, IPSL, available at: http://www.nemoocean.eu/content/download/15482/73217/file/NEMO_book_ _v3_3.pdf (last access: 1 December 2014), 2008.

Madec, G. and Imbard, M.-A.: Global ocean mesh to overcome the North Pole singularity, Clim. Dynam., 12, 381-388, 1996.

Madec, G., Delecluse, P., Imbard, M., and Levy C.: OPA version 8.1 Ocean general circulation model reference manual, LODYC, Technical Report, 91 pp. available at: http://www.nemo-ocean.eu/About-NEMO/Referencemanuals, 1997.

Marshall, S. J., Clarke, G. K. C.: Ice sheet inception: subgrid hypsometric parameterization of mass balance in an ice sheet model, Clim. Dyn., 15, 533-550, 1999.

Marti O., Braconnot, P., Dufresne, J.-L., Bellier, J., Benshila, R., Bony, S., Brockmann, P., Cadule, P., Caubel, A., Codron, F., de Noblet, N., Denvil, S., Fairhead, L., Fichefet, T., Foujols, M.-A., Friedlingstein, P., Goosse, H., Grandpeix, J.-Y., Guilyardi, E., Hourdin, F., Krinner, G., Lévy, C., Madec, G., Mignot, J., Musat, I., Swingedouw, D. 
and Talandier, C.: Key features of the IPSL ocean atmosphere model and its sensitivity to atmospheric resolution, Clim. Dynam., 34, 1-26, http://dx.doi.org/10.1007/s00382-009-0640-6, 2010.

Miller, K. G., Wright, J. D., Browning, J. V., Kulpecz, A., Kominz, M., Naish, T. R., Cramer, B. S., Rosenthal, Y., Peltier, R., and Sosdian, S.: High tide of the warm Pliocene: Implications of global sea level for Antarctic deglaciation, Geology, 40, 407-410, doi:10.1130/G32869.1, 2012.

Mudelsee, M. and Raymo, M.: Slow dynamics of the Northern hemisphere glaciation, Paleoceanography, 20, PA4022, doi:10.129/2005PA001153, 2005 .

Murray, R. J.: Explicit generation of orthogonal grids for ocean models. J. Comput. Phys., 126, 251-273, 1996.

Paillard, D., Labeyrie, L. and Yiou, P.: Macintosh program performs timeseries analysis, EosTrans. AGU, 77, 379, 1996.

Pollard, D., DeConto, R. M., Hysteresis in Cenozoic Antarctic ice-sheet variations, Global and Planetary Change, 45, 9-21, 2005.

Peyaud, V., Ritz, C., and Krinner, G.: Modelling the Early Weichselian Eurasian Ice Sheets: role of ice shelves and influence of ice-dammed lakes, Clim. Past, 3, 375-386, doi:10.5194/cp-3-375-2007, 2007. Departures from eustasy in Pliocene sea-level records, Nature Geoscience, 4, 328-332, 2011.

Reeh, N.: Parametrization of melt rate and surface temperature on the Greenland ice-sheet, Polarforschung, 59, 11-128, 1991. 
Rovere, A., Raymo, M.E., Mitrovica, J.X., Hearty, P.J., OLeary, M.J., Inglis, J.D.: The Mid-Pliocene sea-level conundrum: Glacial isostasy, eustasy and dynamic topography, Earth and Planet. Sci. Lett., 387, 27-33, DOI: 10.1016/j.epsl.2013.10.030, 2014.

Salzmann, U., Haywood, A. M., Lunt, D. J., Valdes, P. J., and Hill, D. J.: 875 A new global biome reconstruction and data-model comparison for the Middle Pliocene, Global Eco. Biogeogr., 17, 432- 447, 2008.

Salzmann, U., Dolan, A. M., Haywood, A. M., Chan, W-L., Hill, D. J., Voss, J., Abe-Ouchi, A., Otto-Bliesner, B., Bragg, F., Chandler, M. A., 
Contoux, C., Dowsett, H. J., Jost, A., Kamae, Y., Lohmann, G., Lunt, D. J., Pickering, S. J., Pound, M. J., Ramstein, G., Rosenbloom, N. A., Sohl, L., Stepanek, C., Ueda, H. and Zhang, Z.: Challenges in quantifying terrestrial warming of the Pliocene revealed by data-model discord, Nature Clim. Change, 3, 969-974, doi:10.1038/nclimate2008 2013.

Seki, O., Foster, G. F., Schmidt, D. N., Mackensen, A., Kawamura, K. and Pancost, R. D.: Alkenone and boron-based Pliocene pCO2 records, Earth and Planet. Sci. Lett., 292, 201-211, 2010.

Solgaard, A.M., Langen, P.L.: Multistability of the Greenland Ice sheet and the effects of an adaptive mass balance formulation, Clim. Dyn., 39, 1599-1612, DOI 10.1007/s00382-012-1305-4, 2012.

Solgaard, A.M., Bonow, J.M., Langen, P.L., Japsen, P., Hvidberg, C.S.: Mountain building and the initiation of the Greenland Ice Sheet, Palaeogeography, Palaeoclimatology, Palaeoecology 392, 161176, 2013.

Stone, E. J. and Lunt, D. J.: The role of vegetation feedbacks on Greenland glaciation, Clim. Dynam., 40, 2671-2686, 2013.

Tarasov, L. and Peltier, W. R.: Greenland glacial history and local geodynamic consequences, Geophys. J. Int., 150, 198229, 2002.

Toniazzo, T., Gregory, J.M., Huybrechts, P.: Climatic impact of a Greenland deglaciation and its possible irreversibility, J. Clim., 17, 21-33, 2004.

Valcke, S.: OASIS3 user guide (prism 2-5), PRISM report no 2. Tech. Rep. TR/CMGC/06/73, CERFACS, Toulouse, France, 60 pp., 2006.

Woillez, M.-N., Levavasseur, G., Daniau, A.-L., Kageyama, M., Urrego, D. H. and Sánchez-Goñi, M.-F. and Hanquiez, V.: Impact of precession on 
the climate, vegetation and fire activity in southern Africa during MIS4, Clim. Past, 10, 1165-1182, doi:10.5194/cp-10-1165-2014, 2014.

905 Wolf, T.C.W. and Thiede, J.: History of terrigenous sedimentation during the past 10 my in the North Atlantic (ODP-Legs 104, 105, and DSDP-Leg 81). Marine Geology, 101, 83-102, 1991.

Yan, Q., Zhang, Z., Wang, H., Zhang, R.: Simulation of Greenland ice sheet during the mid-Pliocene warm period, Chi. Sci. Bull., DOI $910 \quad 10.1007 / \mathrm{s} 11434-013-0001-\mathrm{z}, 2014$. 
Highlights:

1/ we investigate which conditions lead to Greenland Ice Sheet inception during the Pliocene

2/ we show there is no ice sheet inception unless combining low summer insolation and $\mathrm{CO} 2$ levels below modern values

3/ we show that ice sheet is restricted to East and South mountainous regions

4/ we suggest Greenland Ice Sheet inception was a long term, cumulative process rather than abrupt one 